The Concept of a Social Formation in the Writings of E. P. Thompson and Ellen Meiksins Wood

\author{
Tony Burns
}

School of Politics \& International Relations

University of Nottingham

Capital \& Class

Accepted for Publication $8^{\text {th }}$ March, 2021 


\title{
The Concept of a Social Formation in the Writings of E. P. Thompson and Ellen Meiksins Wood
}

\begin{abstract}
'In all forms of society (Gesellschaftsformen) there is one specific mode of production which predominates over the rest, whose relations thus assign rank and influence to the others. It is a general illumination which bathes all the other colours and modifies their particularity. It is a particular ether which determines the specific gravity of every being which has materialized within it.'
\end{abstract}

Marx, Grundrisse ${ }^{1}$

\section{Introduction}

In this article I consider what E. P. Thompson and Ellen Meiksins Wood have to say about the concept of a social formation and its significance for Marxism. The focal passage from the General Introduction to Marx's Grundrisse cited above is particularly significant for the discussion which follows (Marx, 1973 (1857-1858), 106-07). It expresses very well one of the two key features of the concept of a social formation as Marx understands it, which is the idea that a particular social formation (Gesellschaftsformen), or a particular society (Gesellschaft), for example that of England in the sixteenth century, is likely to have an economic system which is composed of more than one mode of production. I refer to this as the notion of modal combination. The other key feature of Marx's understanding of the concept of a social formation is the idea of the reciprocal interaction of base and superstructure within any given social formation.

In my view the concept of social formation ought not to be associated exclusively with Louis Althusser and the structuralist Marxism of the nineteen sixties, for it is clearly to be found in Marx's own writings, especially but not only in the focal passage above. I also think that it is necessary to deploy this concept if we wish to understand Marx's views regarding the transition from feudalism to capitalism in England in the early modern period (roughly 1450-1650 CE).

Both E. P. Thompson and Ellen Meiksins Wood have interesting things to say about this issue. I consider their views together for two reasons. In the first place, Meiksins Wood owes a great deal to her engagement with Thompson's writings. For example her Democracy Against Capitalism contains two chapters which are devoted to a discussion of Thompson's ideas (Meiksins Wood, 20oob-c (1995), 49-75, 76-107). Indeed, there are occasions when she presents herself as being simply a follower of Thompson and as an adherent of his particular version of Marxism (Meiksins Wood, 1995a: 13; 1995c, 52-54, 5875). Indeed, she states at one point that 'I use his [Thompson's] work as a point of departure for reconstructing some of the fundamental categories of historical materialism - notable the metaphor of "base and superstructure and the concept of class' (Meiksins Wood, 20ooa (1995), 13). Meiksins Wood endorses Thompson's criticisms of Louis Althusser and structuralist Marxism (Thompson, 1981a, 196; see also Hirst, 1985a; 
Nield \& Seed, 1979). In rejecting the idea of a social formation, which she wrongly considers to be Althusserian, she thinks of herself as simply following Thompson's critique in The Poverty of Theory, especially his claim that it is excessively theoretical or 'philosophical,' and insufficiently 'historical' (Meiksins Wood, 1995, 13, 49-59).

In the second place, despite Meiksins Wood claim that she is simply following a lead provided by E. P. Thompson, it seems to me that there is in fact a significant (though unacknowledged) difference between her views and those of Thompson regarding this particular issue. For Thompson's attitude towards the concept of a social formation (and those Marxists who employ it) is far more positive than that of Meiksins Wood. It is arguable that Meiksins Wood departs significantly from the position that is adopted by Thompson when she criticizes those who think that this concept ought to be included rather than excluded from the lexicon of Marxism.

The structure of the discussion is as follows. The paper has three parts. In the first I say something about the part that the concept of a social formation has to play in arx's writings. In the second, I discuss what E. P. Thompson has to say about the concept of a social formation, and about the focal passage from Marx's Grundrisse cited above. Finally, I consider the views of Ellen Meiksins Wood and her reasons for objecting to the use of this concept by Marxists.

1

\section{Marx and the Concept of a Social Formation}

In his Theories of Surplus Value (1862-63), echoing the words which he uses in the focal passage from the Grundrisse cited above, Marx states that in nineteenth century English society it is industrial capital which is the specific form of capital which 'gives the whole process of social production its distinctive character,' which 'dominates it,' and which in consequence 'revolutionises all social and political relationships' (Marx, 1972 (18621863), 427). There Marx refers here to 'the whole process of social production' within the economic system of a particular social formation, which he assumes contains more than one mode of production.

If we consider the history of capitalism, understood specifically as a mode of production, Marx argues that this first emerges in Western Europe in the late Middle Ages, from the late thirteenth century onwards. In the Grundrisse (1857-1858), he says that 'capital as trading capital or as money capital' first came into existence 'where capital,' that is to say, the capitalist mode of production, 'was not yet the predominant element' (Marx, 1973 (1857-1858), 108). Similarly, in volume one of Capital (1867), he states that the first beginnings of capitalist production' developed in Europe, in a number of feudal social formations, around the Mediterranean basin, 'as early as the fourteenth or fifteenth century' (Marx, 1974a (1867), 669). There he associates the capitalist mode of production, not only with the 'conversion of products into commodities,' for that occurred to some extent in the case of earlier modes of production, but also with 'the conversion of men into producers of commodities' (Marx, 1974a (1867), 83). Marx accepts that this too existed to some extent, albeit on a small-scale, in pre-capitalist social formations which 
were dominated by earlier modes of production. He insists, however, that in these earlier social formations, although capitalist production did exist, nevertheless it held 'a subordinate place,' which, however, 'increases in importance' as these social formations 'approach nearer and nearer to their dissolution' (Marx, 1974a (1867), 83).

Marx argues that although it is true that capitalism as a mode of production first emerged in Europe in the late medieval period, as early as the fourteenth century, nevertheless this is not true of capitalism as a social formation. In his view, the first social formation which might properly be described as capitalist only came into existence later, after the capitalist mode of production had 'taken hold' in medieval society, had expanded, developed and (eventually) become dominant. As he puts it in the Capital, Volume One, 'although we come across the first beginnings of capitalist production as early as the fourteenth or fifteenth century, sporadically, in certain towns of the Mediterranean,' nevertheless, 'the capitalistic era' proper, containing the first capitalist social formation, in the strict sense of the term, 'dates from the sixteenth century' (Marx, 1974a (1867), 669). Marx suggests that this transition first took place in sixteenth century England and that it was associated with the development of the capitalist mode of production in agriculture there, especially but not only having to do with the trade in wool (Marx, 1974a (1867), 670 ).

In volume 3 of Capital, Marx associated the notion of a social formation with that of a combination of two different modes of production. There he argues that the capitalist mode of production existed in the feudal social formations of the medieval period, but only sporadically. He states that, in pre-capitalist social formations, 'capital,' that is to say the capitalist mode of production, 'has not yet completely,' but has only 'sporadically, brought social labour under its control' (Marx, 1974, 783). It had not yet achieved the dominance which it was to achieve later, at which time it becomes appropriate to talk about the transition from a feudal to a capitalist social formation having taken place. He makes similar remarks in Part Three of his Theories of Surplus Value (Marx, 1972 (1862-1863), 399-452). There he again argues there that it is 'only when the capitalist mode of production has become predominant' in a particular society, or 'when it does not merely exist sporadically ('sporadisch'), but has subordinated to itself the mode of production of society' as a whole, that we might properly speak of the presence of a capitalist social formation (Marx, 1972 (1862-1863), 420).

In order to capture this idea, when discussing the development of capitalism in England, Marx talks about the capitalist mode of production emerging 'intermittently,' 'locally or 'sporadically' in the 'pores,' or the 'interstices,' of the English social formation and then growing, developing and expanding over time. For example in the Grundrisse, Marx states that 'capital appears at first sporadically or locally, alongside the old modes of production, while exploding them little by little everywhere' (Marx, 1973 (1857-1858), 510; cited Hobsbawm, 1978, 48). Marx also says there that 'manufactures' produced under the capitalist mode of production 'may develop sporadically, locally, in a framework which still belongs to a quite different period,' that is to say, in a feudal social formation (Marx, 1973 (1857-1858), 505; see also 108, 256, 276-77, 469, 495, 506, 511, 858-59). 
Marx accepted, then, that the production of commodities under the capitalist mode of production can take place in pre-capitalist social formations. He acknowledged that it can occur in those social formations where 'the great mass of the objects produced are intended for the immediate requirements of their producers', and are in consequence not 'turned into commodities' (Marx, 1974a (1867), 166). He conceded that the production of commodities by 'free wage-labour' can occur in social formations where 'social production is not yet by a long way dominated in its length and breadth by exchange-value' (Marx, 1974a (1867), 166). Paradoxical though it might seem, a logical implication of these remarks is that in Marx's view, the capitalist mode of production may be present in social formations which are not capitalist.

As the focal passage cited above suggests, Marx distinguishes clearly between the concept of a mode of production and that of a social formation. He thinks of the economic base of particular societies as being composed of more than one mode of production in combination with one another. At various times he employs the words 'feudal' and 'feudalism,' as well as the words 'capitalist' and 'capitalism,' to refer either to a particular mode of production or to a particular social formation or to a type of society. When using these terms to refer to social formations he suggests that the reason why a social formation as a whole may be characterised as being either feudal or capitalist is because the social relations which are associated with one of these two modes of production are dominant in relation to those of the other. On this view, what makes it appropriate to describe a social formation in a particular way is not the complete absence of other modes of production within it, but simply the subordination (or 'subsumption') of these other modes to the mode of production which happens to be dominant.

In my view the distinction which Marx makes between the concept of a social formation and the concept of a mode of production is essential for Marxist historians who wish to understand his views regarding the transition from feudalism to capitalism in England from the late fourteenth century onwards. There is a great deal of literature which discusses this issue (Dobb, 1946; Hilton, 1980 [1976); Brenner, 1977; Aston \& Philpin, 1985). However, virtually all of it suffers from the fact that those who have contributed to the transition debate do not address explicitly the distinction between the concept of a mode of production and that of a social formation. Nor do they appear to regard the concept of a social formation as being of any great significance. At least, they do not invoke the concept explicitly in their writings, even if they rely on it implicitly.

\section{2}

\section{E. P. Thompson and the Concept of a Social Formation}

Despite his criticisms of Althusserian Marxism in 'The Poverty of Theory,' it is far from clear that E. P. Thompson objects to the use of the concept of a social formation by Marxist historians (Thompson, 1981a). Nor is it evident that Thompson associates this concept exclusively with Louis Althusser and structuralist Marxism. Thompson employs the expression 'social formation' on his own account on several occasions in 'The Poverty of Theory.' Moreover, when he does so, his attitude is always positive and never 
critical (Thompson, 1981a (1978), 20, 47-48, 50, 56, 61, 86, 88, 91, 93, 97, 108, 110, 142, 157, $159,163,170,179)$. For example, at one point he observes that, in contrast to the standpoint of political economy, or that of economic 'theory,' that of the historian, properly understood, necessarily involves 'talking about men and women, in their material life, in their determinate relationships.' Moreover, Thompson goes on, 'by determinate relationships' he has in mind relationships structured within particular social formations in class ways' (Thompson, 1981a (1978), 97). On another occasion Thompson maintains that it is certainly true - and it is generally held to be a fundamental Marxist proposition - that there is some correspondence between a given mode of production and a social formation (including political and ideological forms)' (Thompson, 1981a (1978), 157).

In Thompson's thought the meaning of the concept of a social formation is closely related to that of capitalism. In the case of capitalism, that meaning is ambiguous. This is so because, as we have seen, the words 'capitalism' and 'capitalist' may be used to refer either to a particular mode of production or, alternatively, to an entire society or social formation. Failure to distinguish between the two different senses of these terms is a weakness in the thinking of Ellen Meiksins Wood. E. P. Thompson does appreciate the significance of this terminological distinction. In 'The Poverty of Theory' he makes a point of distinguishing between the concept of 'capital' and that of 'capitalism' [his emphasis] (Thompson, 1981a (1978), 61, 154). Here the word 'capital' is used to refer to a category taken from political economy. It may be associated with a society's mode of production, narrowly conceived. According to Thompson, the word 'capitalism,' on the other hand, should be used to refer to an entire social formation. To illustrate this, Thompson maintains at one point that 'capital is an operative category which laws its own development,' whereas 'capitalism is the effect, in social formations, of these laws' (Thompson, 1981a (1978), 61). On another occasion he emphasises the fact that the 'capitalist mode of production,' again narrowly conceived, 'is not capitalism' as he understands the term (Thompson, 1981a (1978), 154). In Thompson's view, the political economist is concerned with 'capital,' or the capitalist mode of production, again narrowly conceived. The historian, on the other hand, is necessarily interested in 'capitalism,' or in what goes on within an entire social formation as it develops over time.

In 'The Poverty of Theory' Thompson associates the concept of 'capital' with political economy, or with pure economic 'theory,' and that of 'capitalism' with history and the craft of the historian. He argues that if we move from a discussion of the concept of 'capital' to a discussion of the concept of 'capitalism,' then we pass 'from the adjectival characterisation of a mode of production (a concept within Political Economy, albeit within Marxist anti Political Economy) to a noun descriptive of a social formation in the totality of its relations' (Thompson, 1981a (1978), 154). In so doing, we enter the world of the historian. As Harvey J. Kaye has noted, this amounts to the claim that the aim of Marxist historians is to offer 'an organic conception of the social whole' (Kaye, 1984, 173). In Thompson's view, the principal task of Marxist historians is to offer 'study social process in its totality' (Thompson, 1981a (1978), 70). It is to offer 'a total history of society, in which all other sectoral histories are convened' (Thompson, 1981a (1978), 70). 
In short, it is to present an account, not of a mode of production, narrowly conceived, but of an entire social formation, again in all of its social relations.

As a historian, Thompson uses the term 'capitalism' specifically to refer to an entire capitalist society, understood as a totality or whole. He argues that, unlike political economists, Marxist historians should seek to 'offer a total account of society or of its history' (Thompson, 1981a (1978), 60). This is something which, in his opinion, the political economist cannot do. Political economy 'cannot show capitalism,' or 'capital in the totality of its relations,' for, unlike the discipline of history, it has 'no language or terms to do this' (Thompson, 1981a (1978), 62). This amounts to saying that, in Thompson's view, political economy can only take Marxist historians so far. It provides them with knowledge of the capitalist mode of production only, or of the economic basis of a capitalist society or social formation, in short of 'capital,' but not of 'capitalism,' that is to say, of any particular capitalist society or social formation, again understood as a totality as a whole. For knowledge of that kind, Thompson argues, Marxist historians must go beyond political economy, whilst also retaining its insights. They must move from considering capital as a mode of production, to thinking of capitalism as a social formation. Consequently, the task of the historian is to pay due attention to concrete specificities, as well as to the influence of cultural and other superstructural factors in the 'causation' of historical events. It is this concrete entity, a particular social formation as a whole, including of course what might be regarded as its superstructural elements, which for Thompson provides the proper subject matter for the historian.

This way of thinking influences Thompson's understanding of Marx's Capital. In 'The Poverty of Theory,' Thompson agrees with the view of Louis Althusser that Capital is not a work of "history",' or of 'real history' (Thompson, 1981a (1978), 57). Thompson insists that 'Marx never pretended, when writing Capital, that he was writing the history of capitalism' (Thompson, 1981a (1978), 57). Thompson therefore agrees with Althusser's view that Capital is primarily a work of political economy, rather than a work of history. He also concedes that Marx's work focuses primarily on capitalism understood as a mode of production. It was not intended by its author to be a history of capitalism, or a history of the English social formation in the nineteenth century.

It is an implication of this account of his views that, unlike Ellen Meiksins Wood, E. P. Thompson does not reject the concept of a social formation as something which is alien to Marxism. Nor does he argue that it is an unwelcome accretion to the lexicon of Marxism as a consequence of the malign influence Louis Althusser. On the contrary, Thompson invokes this concept himself. He explicitly identifies the concept of 'capitalism,' as he understands it, the referent of which in his view provides the proper subject matter for the historian, with the idea of a social formation. It would be far more accurate to say that what Thompson objects to is not so much the use of the concept of a social formation by Althusser and his followers but, rather, the particular way in which (in his opinion) they think about this concept.

Thompson argues (wrongly) in 'The Poverty of Theory' that Althusser 'wishes to return us' (Marxists) 'to the conceptual prison (mode of production = social formation)' which 
'had been imposed upon Marx' by those of his critics who associate the concept of a social formation with determinism and reductionism. According to Thompson, these critics erroneously attribute to Marx and Marxism the view that there is nothing more to a social formation, or nothing else which matters so far as historians are concerned, than the fact that a given social formation happens to be associated with a particular mode of production. In Thompson's opinion, then, just like those orthodox or vulgar Marxists who came before him, Louis Althusser is a determinist and a reductionist who attaches no significance at all to the workings of superstructural factors in the 'causation' of historical events (Thompson, 1981a (1978), 163). This view has been criticised by Perry Anderson, with some justification (Anderson, 1980, 64-68).

\section{E. P. Thompson and the Focal Passage from Marx's Grundrisse}

As Ellen Meiksins Wood has noted, in his 'The Poverty of Theory' Thompson refers on several occasions to Marx's 'Grundrisse face' (Meiksins Wood, 1995c, 53, 58, 6ofn13; Thompson, 1981a, 74, 88, 163, 169). By this phrase, Thompson has in mind Marx as a political economist, as opposed to Marx as a historian. He is not, therefore, on the whole sympathetic to Marx when he puts on this Grundrisse face. Thompson tends to associate this aspect of Marx's thought with structuralism (in the broad sense of the term), and therefore also with determinism and a denial of the possibility of human agency, that is to say the possibility of spontaneity and creativity in human conduct. Indeed, those who follow this aspect of Marx's thought, tend to think in terms of human behaviour rather than action. There are times when Thompson associates such ideas with the psychological behaviourism of Ivan Pavlov and B. F. Skinner, which in his view denies that there is any significant difference between human beings and non-human species of animal.

Thinking of this kind is central to Thompson's understating of Marxism as a 'humanism' in his relatively early essay on 'Socialist Humanism' (1957a-b). There Thompson argues that Stalinism or orthodox Marxism 'attempts to short-circuit the processes of social life' by 'asserting economic, i.e. class, interests as the only "real" sources of human motivation' (Thompson, 1957a, 122). According to Thompson, this 'entirely mistakes man's nature,' because, as in the case of psychological behaviourism, it does not recognise any significant difference between human beings and non-human animals. The Stalinist, Thompson maintains, 'is fixated by Pavlov's dogs: if a bell was rung, they salivated. If an economic crisis comes the people will salivate good "Marxist-Leninist" belief.' However, he goes on, 'Roundhead, Leveller, and Cavalier, Chartist and AntiCorn Law Leaguer, were not dogs; they did not salivate their creeds in response to economic stimuli; they loved and hated, argued, thought, and made moral choices' (Thompson, 1957a, 122).

B. F. Skinner, in Beyond Freedom and Dignity, maintains that there is a 'traditional' view of human nature which is given a classic expression in the following lines from Shakespeare's Hamlet (Act II, Scene 2): 'What a piece of work is a man! how infinite in faculty! in form and moving how express and admirable! in action how like an angel! in apprehension how like a god! the beauty of the world! the paragon of animals!' (Skinner, 
1972, 196). According to Skinner, this traditional humanist view is both metaphysical and unscientific. In contrast, Skinner points out, the behavioural scientist Ivan Pavlov 'emphasised "How like a dog!" is man. In Skinner's opinion, so far as our understanding of human nature is concerned, this change of view by Pavlov 'was a step forward.' This is so because 'a god is the archetypal pattern of an explanatory fiction, of a miracle working mind, of the metaphysical.' Man is of course, Skinner concedes, 'much more than a dog.' However, by this he means simply that, physiologically speaking, human beings are far more complex organisms than 'lower' species of animals. Nevertheless, Skinner insists that, just 'like a dog' and other animal species, man does fall 'within range of scientific analysis' (Skinner, 1972, 196). Skinner's principal reason for thinking this is his belief that, like that of other animals, including rats and pigeons as well as dogs, human behaviour is in its entirety causally predetermined. As R. A. Bauer has noted, the ideas which are associated with psychological behaviourism, as they are to be found in the writings of Pavlov, had a significant influence of Soviet psychologists in the nineteen twenties (Bauer, 1981 (1952), 49-66; see also Cornforth, 1974 (1954), 9-21; Graham, 1987, 158-63; Malinin et. al., 1974, 104; McLeish, 1959, 83-84).

It is clear from what E. P. Thompson says about this issue in the essay 'Socialist Humanism' that he strongly disagreed with both Ivan Pavlov and B. F. Skinner on this issue and that he defends the traditional humanist view of nature that is expressed by Shakespeare. In Thompson's view, the difference between human beings and nonhuman animal species, such as dogs, is the presence in the former of consciousness or rather, more specifically, 'human consciousness,' which includes of course the presence of self-consciousness and 'moral consciousness,' each of which is a necessary preconditions for human agency (Thompson, 1957a, 122). As Thompson puts it, 'economic changes impel changes in social relationships, in relations between real men and women.' These, in turn, 'are apprehended, felt, reveal themselves in feelings of injustice, frustration, aspirations for social change,' and all of this 'is fought out in the human consciousness, including the moral consciousness.' If this were not so, Thompson insists, then 'men (sic) would be-not dogs—but ants.' Again, however, to think in this way is to entirely misunderstand human nature, or what it is to be a human being. For in Thompson's view 'it is precisely the element of agency which distinguishes' human being 'from the beasts.' It is this only which constitutes 'the human part of man, and which it is the business of our consciousness to increase' (Thompson, 1957a, 122). What 'Pavlovian behaviourism' forgets, or overlooks, is the creative spark without which man would not be man' (Thompson, 1957b, 125).

Despite his critical remarks concerning Marx's 'Grundrisse face,' Thompson's engagement with Marx's ideas in the General Introduction to the Grundrisse is not always critical. Indeed, there are occasions when he is extremely positive about the views which Marx expresses there, especially in what I have been calling the focal passage. The importance that Thompson attached to this passage has been noted by more than one commentator (Kaye, 1984, 205; Meiksins Wood, 1995c, 63, 69). Thompson discusses the focal passage in three places, namely 1. 'The Poverty of Theory'; 2. in an article entitled 'Eighteenth Century English Society: Class Struggle without Class,' published in 1978; and 3. in an article entitled 'Folklore, Anthropology and Social History,' also published in 1978 (Thompson, 1981a (1978), 157; Thompson, 1978a 151-52; 
Thompson, 1978b, 261, 264). In all three cases Thompson is interested in the implications of what Marx has to say in this passage for our understanding of the distinction between base and superstructure which is drawn in the Preface to $A$ Contribution to a Critique of Political Economy. Thompson considers this to be a metaphor. It is, moreover, a metaphor of which he disapproves, because of its association with determinism and reductionism. In his view, Marx employs a very different metaphor in the focal passage, one which employs colour imagery, and which is associated with the idea of a 'general illumination' of all of the social relationships which are to be found in an entire social formation, understood, as we have seen, as a totality or whole. Thompson prefers this alternative metaphor because, in his opinion, it takes us away from the base superstructure motif and is in consequence not associated with determinism and reductionism.

In 'The Poverty of Theory' Thompson calls Marx's general illumination metaphor an 'enigmatic but suggestive' analogy, without explaining to his readers why he thinks that this is the case (Thompson, 1981a (1978), 157). He also refers to 'the rich hypotheses which appear in its interstices,' especially those relating to 'pre-capitalist formations' (Thompson, 1981a (1978), 157). In 'Eighteenth Century English Society: Class Struggle Without Class,' he maintains that although Marx's reference to 'rank and influence', 'general illumination' and 'tonalities' in the focal passage is itself a metaphor, nevertheless, 'I prefer it, for many purposes' to Marx's 'subsequent metaphor of "basis" and "superstructure," because it is less likely 'to congeal a fluent social process' (Thompson, 1978b, 151-52). Thompson's other reasons for approving of Marx's 'general illumination' metaphor in the focal passage, and for thinking that it takes us away from thinking in terms of base and superstructure, are all given in his article 'Folklore, Anthropology and Social History.' There Thompson claims that Marx's remarks in the focal passage are suggesting of the notion of 'simultaneity,' as he understands that term. The base superstructure metaphor, he argues, involves the 'employment of too narrow a category, "economic" (Thompson, 1978, 261). The 'general illumination' metaphor in the focal passage, on the other hand, emphasises 'the simultaneity of expression of characteristic production relations in all systems and areas of social life.' Consequently, it takes us away from "any notion of the primacy (more "real") of the "economic," with the norms and culture seen as some secondary "reflection" of the primary" (Thompson, 1978b, 261).

In Thompson's opinion, the views expressed by Marx in the focal passage evince a much more expansive understanding of a particular society or social formation's mode of production than that which is associated with the base-superstructure idea, as we find it in orthodox Marxism. Thompson holds that it is a mode of production understood in this broad sense of the term, which includes a reference to cultural norms and to phenomena which are usually regarded as superstructural, that Marx has in mind in the focal passage. In Thompson's account of Marx's views, it is the mode of production (in this broad sense) of a given social formation, and not any mode of production conceived in narrowly economic terms, which provides "the general illumination into which all other colours are plunged and which modifies their specific tonalities"' (Thompson, 1978b, 264). 
According to Thompson, Marx in the focal passage is working with the idea of a society or a social formation understood as a totality or whole, within which all social relations are mutually imbricated. Thompson holds that principle of reciprocal interaction, not so much of base and superstructure, but rather of social being and consciousness, lies at the very heart of Marx's social theory in this key passage from the Grundrisse. Moreover, it is this idea, above all, which is expressed by Marx's employment of the 'general illumination' metaphor. Invoking again an idea taken from optics, this time the notion of 'refraction,' Thompson maintains that for Marx, in all social formations, understood in this way, "historical change eventuates, not because a given "basis" must give rise to a correspondent "superstructure," but because changes in productive relationships are experienced [his emphasis] in social and cultural life' (Thompson, 1994a, 222). To capture this idea, Thompson states that those changes in human experience which constitute social life are necessarily 'refracted in men's ideas and their values, and argued through in their actions, their choices and their beliefs' (Thompson, 1994a, 222).

Nevertheless, Thompson's proposed interpretation of the focal passage from Marx's Grundrisse is open to question. In particular, it is not so clear that what Marx says there does point towards he outright rejection of the base-superstructure distinction, as opposed to suggesting that we Marxist historians should change the way they think about it. Nor does the focal passage obviously invoke the notion of reciprocal interaction, whether this is understood in the way that Thompson understands it, or in any other way, such as for example the reciprocal interaction, not of social being and consciousness, but rather of base and superstructure. It is true that the notion of reciprocal interaction is central to Marx's thinking generally. Nevertheless, it is difficult to defend the view that it is this idea specifically that Marx has in mind in the focal passage, rather than the notion of modal combination.

A far more plausible reading of the focal passage, although one which is largely overlooked by E. P. Thompson, is that it expresses Marx's idea of modal combination, that is to say, the combination of more than one mode of production within a given social formation. Thompson has difficulty appreciating this precisely because his understanding of the concept of a mode of production is so broad that, from the standpoint of his reading of Marx's social theory, there could be only one mode of production in any given social formation. I say 'largely overlooked' above because in 'The Poverty of Theory,' when talking about Marx's Grundrisse, Thompson does refer at one point to 'the rich hypotheses which appear in its interstices,' especially those relating to 'pre-capitalist formations' (Thompson, 1981a (1978), 59). It seems to me that when making this remark Thompson does, on this occasion at least, if only implicitly, acknowledge the significance which the principle of modal combination has for Marx in the Grundrisse. Moreover, as Perry Anderson has pointed out, in 'The Poverty of Theory' Thompson also refers at one point to the existence of 'overlapping modes of production' in the social formation of India (Thompson, 1981a, 161). 


\section{Ellen Meiksins Wood and the Concept of a Social Formation}

Ellen Meiksins Wood has a tendency (in my view wrongly) to associate the concept of a social formation, not with Marx himself, but rather with Louis Althusser and structuralist Marxism. This seems to be her principal reason for objecting to it. She has three criticisms, in particular, of those Marxists who employ the concept, two of which are made explicitly and the third implicitly. The first (explicit) criticism is that their reading of Marx is based on an erroneous translation of the German term Gesellschaftsformen in the focal passage from Marx's Grundrisse. The second (also explicit) criticism is that those who deploy the concept of a social formation when discussing the emergence and development of capitalism entangle themselves in a circular argument. Meiksins Wood's third criticism (which is made implicitly) is that the concept of a social formation is inextricably associated with that of teleology and therefore, also, with determinism. I shall discuss these criticisms in turn.

\section{Wood's First Criticism: The Issue of Translation}

Regarding the translation into English of Marx's German text, Meiksins Wood makes two observations. The first has to do with words and the second with concepts. As to the choice of words, she argues that it is a mistake to translate the German term Gesellschaftsformen in the focal passage from the Grundrisse as 'social formation,' and claims that a better (because more literal) translation would be 'form of society.' Nor is she alone in this. As Chris Arthur has pointed out, in his authoritative 'Guide to Marx's Grundrisse in English' (2008), there have been two full-length translations of Marx's text in the last few decades, namely that of Martin Nicolaus for the Penguin edition (1973) and that of Ernst Wangermann for the more recent edition of the Collected Works of Marx and Engels (2010). In both cases the German term is translated into English as 'form of society' rather than 'social formation.'

On the other hand however, S. W. Ryazanskaya, in her translation of the General Introduction to the Grundrisse, consistently renders Marx's Gesellschaftsformen as 'social formation' (Marx, 1981 (1859), 188-217). Moreover, despite generally preferring the translation of Wangermann to that of Nicolaus, Arthur reproduces that of Ryazanskaya in his well-known abridged student edition of The German Ideology (Marx and Engels, $2001(1845), 124-52)$. My own view is that whether the term Gesellschaftsformen is translated as 'social formation' or as 'form of society' is a matter of relatively little importance. No matter which of the two phrases is used, it is the concept of modal combination that is implied by the use of the German term, which really matters.

So far as the conceptual side of things is concerned, Meiksins Wood claims that the term Gesellschaftsformen does not mean the same thing or express the same concept for Marx that the term 'social formation' means (and expresses) for structuralist Marxists. She insists that 'Marx's own use of the concept rendered by the Althusserians as "social formation"' actually 'differs substantially' in meaning from that which is attributed to it by structuralist Marxists such as 'Althusser, Balibar or Poulantzas' (Meiksins Wood, 
200ob, 57). I do not agree with this view. It is therefore necessary at this point to clarify the meaning of the term Gesellschaftsformen, as it is used by Marx in the focal passage.

Etienne Balibar, Nicos Poulantzas and Perry Anderson all maintain that for Marx the term Gesellschaftsformen is a technical way of referring to what the language of everyday life indicates as a particular society, for example that of classical Athens, England in the sixteenth century, and France or Russia in the nineteenth century, the point being to draw attention to the fact that the society in question contains an economic system which combines more than one mode of production (Balibar, 2015 (1968), 365-66fn5; Poulantzas, 1976 (1968), 15; Anderson, 1988 (1974), 22fn6). Meiksins Wood takes issue with this view. In her opinion when Marx employs the term Gesellschaftsformen he has in mind, not particular societies understood in this way, but rather particular types or forms of society. She maintains that there is a significant difference between talking about a particular society, on the one hand, and talking about a particular form of society on the other.

It must be acknowledged that there is indeed a difference between talking about a particular society, on the one hand, and talking about a particular form of society on the other. However, this is not as significant as Meiksins Wood claims. I say this because Marx states explicitly in the focal passage that in every Gesellschaftsformen 'there is one specific mode of production which predominates over the rest, whose relations this assign rank and influence to the others' (Marx, 1973 (1857-1858), 106-07). As Balibar argues, this clearly implies that Marx believed that all particular societies, no matter what type or form of society they happen to instantiate, possess an economic system which is composed of more than one mode of production. It also implies that Marx employs the term Gesellschaft or 'society' itself in a technical way, such that it is necessarily associated with the idea of modal combination. In short, what is true of a given form of society is also true, a fortiori, of any particular society which instantiates that form.

Etienne Balibar is correct, therefore, when he claims that Marx's use of the word Gesellschaftsformen in the focal passage registers his (Marx's) belief that, whether one is talking about the economic system of any particular form of society, on the one hand, or about the economic system of any particular society instantiating that form, on the other, in both cases Marx assumes that there will be more than one mode of production present, one of which may be dominant. This is the essential point so far as the meaning of the word Gesellschaftsformen is concerned and it is grasped very well by Balibar in his contribution to Reading Capital.

\section{Wood's Second Criticism: The Issue of Circularity}

Meiksins Wood's second criticism of those Marxists who employ the concept of a social formation is that it is associated with circular reasoning about the causes of historical events. For example, she suggests that when talking about the transition from feudalism to capitalism, those Marxists who deploy this concept have a tendency to 'beg the question' by simply assuming from the outset that capitalism already exists in statu 
nascendi within the interstices of feudal society and then later, in and through some quasi-natural and inevitable process of development, it is eventually actualised, as the 'fetters' which held back its development in feudal society were successively removed. Wood maintains that those who utilise the concept of a social formation are therefore guilty of 'assuming' from the outset 'precisely what needs to be explained,' namely the existence of capitalism within the interstices of feudal society (Meiksins Wood, 2ooob, 56fn8). This is one of the principal defects of what she refers to as 'the Althusserian (sic) concept of "social formation"', which assumes that different 'modes of production can coexist' in the same society 'without any need to explain their emergence' (Meiksins Wood, 2000c 115).

I pointed out earlier that Marx, when discussing the emergence and development of capitalism in England in the early modern period, does not only employ the concept of a social formation. He also employs the language of seeds, pores and interstices, to which Meiksins Wood objects so strongly. In effect therefore, Wood's critique applies not only to the views of Althusser, Balibar and Poulantzas but also to those of Marx. This raises the question of whether Marx himself might be criticized along the lines which are suggested by Meiksins Wood. Interestingly, Meiksins Wood maintains that this is indeed the case. She acknowledges that "it was Marx, after all, who first spoke of "fetters" and "interstices"' (Meiksins Wood, 20ooe, 115). Marx too therefore, in her view, 'was, at first, very much a part of th[e] tradition' which she wishes to criticise (Meiksins Wood, 2oood, 149). For example, 'in his earlier accounts of history, there are many of the same assumptions about the existence of a rudimentary capitalism in the ancient world and its interruption by external forces.' In his case also, therefore, 'the existence of capitalism was assumed in order to explain its coming into being, as capitalist impulses, present "in the interstices of feudalism," were liberated by breaking the "fetters" of the feudal system' (Meiksins Wood, 2oood, 149).

Meiksins Wood does not, therefore, think of herself as defending Marx from the theoretical excesses of his structuralist Marxist interpreters. Rather, she thinks that she is rescuing Marx from himself. This is clear from the fact that (ironically, given that she is such a strong critic of Louis Althusser) she refers to a radical break or to a rupture between the views expressed by the young Marx, prior to the writing of the Grundrisse manuscript (1857-1858), and those expressed by the mature Marx both in the Grundrisse and in his later economic writings, including volume one of Capital (1867). As Meiksins Wood puts it, 'sometime between the German Ideology and Capital, with a critical milestone in the Grundrisse, a radical change took place' in Marx's thinking. In consequence, he altered his views regarding the development of capitalism in England and elsewhere and was 'no longer willing to assume the very thing that needed to be explained' (Meiksins Wood, 2oood, 149).

According to Meiksins Wood, this alleged radical change of view on Marx's part can be detected in the Grundrisse, which contains Marx's 'most systematic discussion of precapitalist societies' and in which he 'faces the problem of accounting for the transformation of pre-capitalist into capitalist property relations without assuming the pre-existence of capitalism' (Meiksins Wood, 2oood, 149). In my opinion this reading of the historical trajectory of Marx's intellectual development is implausible. I say this 
because, as we have seen, Marx employs the language of seeds, pores and interstices, together with that of the sporadic development of capitalism, not only prior to the writing of the Grundrisse manuscript but in the manuscript itself (Marx, 1973 (18571858), 108, 256, 276-77, 469, 495, 505-06, 510-11, 858-59). Moreover, he also employs it, somewhat later, in his Theories of Surplus Value (Marx, 1972 (1862-63), 419-20) and in the first and third volumes of Capital (Marx, 1974a (1867), 83, 669); Marx, 1974b (1894), 330-34, 783).

Meiksins Wood claims that Marx himself might also at times justifiably be accused of circular reasoning when talking about the emergence and development of capitalism. However, against this view, it might be argued that Marx's reasoning is not flawed in this way, precisely because he distinguishes clearly between capitalism as a mode of production and capitalism as a social formation. The apparent circularity, indeed logical contradiction, that is identified by Meiksins Wood, which is associated with the view that for Marx capitalism appears to precede and to be the cause of itself, is removed once the distinction between capitalism as a mode of production and capitalism as a social formation has been made. As soon as it is appreciated that the words 'capitalism' and 'capitalist' can be used and are in fact used in these two different senses, it then becomes clear that Marx's reasoning about the emergence and development of capitalism in, say, England in the early modern period is not circular. For all that Marx is claiming is that capitalism in the second sense (the social formation) came into existence as a consequence of the prior emergence of capitalism in the first sense (the mode of production). Of course, Meiksins Wood is right to suggest that this leaves the origins of the capitalist mode of production unexplained. However, that is a separate issue which has nothing to do with the allegation that those like Marx who employ the concept of a social formation are guilty of circular reasoning.

As we saw earlier, when discussing the emergence and development of capitalism in England, Marx does not claim that capitalism was the cause of itself. Rather, he claims that a necessary precondition for the emergence of capitalism, as a social formation, was the prior emergence and development there of the capitalist mode of production, which took place from the late Middle Ages onwards. Marx's employment of the concept of a social formation is not, therefore, to be associated with an alleged circularity in his reasoning about the transition from feudalism to capitalism. On the contrary, this is the very reason why Marx's argument regarding that process of historical development, whatever other faults it may possess, should not be regarded as circular.

Marx's distinction between the concept of a mode of production and that of a social formation also enables us to understand the apparent paradox associated with his belief that a particular society might be both capitalist and also not capitalist at the same time. This paradox, together with the logical contradiction with which it appears to be associated, is removed once it is appreciated that according to Marx capitalist production can take place in a non-capitalist or pre-capitalist social formation. For example, when talking about the emergence and development of capitalism in England, Marx argues that there was a period of time (the so-called transition period) when the capitalist mode of production, although it existed and was expanding and developing, nevertheless co-existed in a subordinate position alongside the dominant feudal mode 
of production, in what might, for that very reason, justifiably be characterised as a feudal and not a capitalist social formation.

\section{Wood's Third Criticism: The Issue of Teleology}

Although Meiksins Wood does not make the point explicitly, another way of formulating her objection to the (alleged) circular reasoning which she associates with use of the concept of a social formation would be to say that it is teleological. Reasoning of this kind invokes the notion of 'final causes,' as Aristotle understands it in his Metaphysics (Aristotle, 1984, 1013a24-1014a25, 1600-01). Meiksins Wood suggests that structuralist Marxists think about the history of the development of capitalism in the same way as Hegel (who followed Aristotle) thinks about the process of the development of an acorn into an oak tree in the Preface to his Phenomenology of Spirit (Hegel, 1977, §12, 7). This is a process of development in which, in accordance with a principle of natural causation, a potential which was always present in a particular organism is necessarily brought to fruition or actualised.

Meiksins Wood suggests that the problem with teleological arguments is that they imply that processes of historical development are necessary. It will inevitably be assumed by historians who reason teleologically that the sequence of events they are attempting to explain could not have happened in any other way than the way in which it did in fact happen. They will therefore conclude that there was only one possible sequence of events that could have happened in the circumstances. In her view, then, it is impossible for those who deploy such arguments to avoid a commitment to some form or other of historical determinism. It is for this reason that Meiksins Wood associates employment of the concept of a social formation with orthodox Marxism and with a deterministic understanding of the materialist conception of history that is based on a casual reading of the preface to Marx's A Contribution to a Critique of Political Economy (2010a (1859), 261-66).

The crucial question here is whether or not Marx's account of the emergence and development of capitalism in England, which does invoke the notion of a social formation, also involves teleological reasoning and therefore, by implication, a commitment to some form of determinism. In my view it does not. For looking back at the end of a historical process of development and claiming that there is a discernible pattern to the sequence of events that one has observed empirically does not necessarily imply that one thinks that this sequence was inevitable, or that the events which are associated with it could not have happened otherwise than they did.

Hannah Arendt, whose relationship to Marx and Marxism is ambivalent, makes an interesting observation about this issue in her essay on "Truth and Politics." She argues that although it is true that in retrospect - that is, in historical perspective - every sequence of events looks as though it could not have happened otherwise,' nevertheless 'this is an optical, or, rather, an existential, illusion.' For, of course, 'nothing could ever happen if reality did not kill, by definition, all the other potentialities originally inherent in any given situation' (Arendt, 1977, 238). According to Arendt, in all historical 
situations it is the case that things might turn out differently from the way in which they do in fact turn out. There is always a contingent element which is associated with historical 'facts,' and therefore also with the writing of history itself. For this reason history is never a necessary affair. In Arendt's words, historical 'facts have no conclusive reason whatever for being what they are,' and 'they could always have been otherwise' than what they actually were (Arendt, 1977, 238, 247).

E. P. Thompson says something similar in The Making of the English Working Class. There Thompson claims that for historians who are of an 'empiricist' disposition, looking back at historical events, 'they appear not only as explicable in their own terms but as inevitable' (Thompson, 2013 (1963), 204). In such accounts, because 'each event is explicable and appears also as a self-sufficient cause of other events, we arrive at a post facto determinism' in which 'the dimension of human agency is lost, and the context of class relations is forgotten' (Thompson, 2013 (1963), 205).

The non-deterministic view that is pointed to by both Arendt and Thompson seems to me to be compatible with Marx's views on history, provided they are properly understood. We saw earlier that Marx's employment of the concept of a social formation does not necessarily lead to the problem of circularity. Now we can also see that, despite Meiksins Wood's suggestion to the contrary, it does not necessarily involve a commitment to teleological reasoning or to a form of historical determinism either. For example, it is consistent with an approach to the explanation of historical events which attaches importance to class struggle as a form of human agency, in the sense in which both E. P. Thompson and Ellen Meiksins Wood understand the term. This is not to say, of course, that this approach to historical explanation ignores or overlooks the significance of economic factors. The point here is that underlying economic processes should be thought of as guiding, shaping or conditioning, rather than determining the specific outcome, of historical processes or sequences of historical events. This is part of what Marxists who employ the concept of a social formation have in mind when they refer to the reciprocal interaction of base and superstructure within a given social formation.

Thinking of this kind is sometimes said to involve the notion of 'determination in the last instance' (Althusser, 1969a (1965) 105, 117-18, 121-23, 125; Althusser, 1969b (1965), 203, 213, 215; Althusser, 2015a (1965), 61; Althusser, 2015b (1965), 244, 246; Balibar, 2015 (1965), 378, 381, 384, 386; Establet, 2015 (1965), 499; Thompson, 1981a, 81-83, 91, 95-96; Thompson, 1994a, 218, 220, 261, 264-65). It seems to me, however, that this is a misnomer. For what we are talking about here is a form of influence which might plausibly be associated with the first instance rather than the last one. By this I mean that, considered from this point of view, historical processes of economic development set the background context, or the broad parameters, within which or between which historical events might possibly occur. In practice which of these possibilities is actualized will depend on the additional operation of other, essentially non-economic (superstructural) factors.

Understood in this way, in any given social formation at any given time, economic processes act so as to delimit the spectrum of available possibilities (the boundary 
limits), so far as the occurrence of historical events is concerned. As Raymond Williams has argued in Marxism and Literature, this involves both the 'setting of limits' and the exertion of pressures' (Williams, 1977, 8). Despite having reservations about the basesuperstructure motif, E. P. Thompson refers favourably to the views of Raymond Williams on base and superstructure on more than one occasion (Thompson, 1981a (1978), 349-51; Thompson, 198ob (1973), 120, 189fn19; Thompson, 1994 (1978), 225fn39).

It is arguable that this is what Marx has in mind when he says, in The Eighteenth Brumaire of Louis Bonaparte, that 'men (sic) make their own history, but they do not make it as they please; they do not make it under self-selected circumstances, but under circumstances existing already, given and transmitted from the past. The tradition of all dead generations weighs like a nightmare on the brains of the living' (Marx, 1958 (1852), 247). On this view, economic processes do not and indeed cannot fix or determine actual historical outcomes, which depend on and are the consequences of the operation of a variety of 'causal' (using this term loosely) forces, including sociological, political and ideological factors, as well as economic ones. In my opinion, E. P. Thompson shared this view. The above passage from Marx's Eighteenth Brumaire expresses very neatly, in summary form, Thompsons's own view of history, as involving both the principle of structure and that of agency, reciprocally interacting with one another.

Ellen Meiksins Wood agrees with E. P. Thompson's opinion that there is no significant difference between orthodox Marxism and the structuralist Marxism of Louis Althusser and Etienne Balibar. For in both cases, it is alleged, we find an outlook which is determinist and reductionist. Meiksins Wood's views on this subject pull in different directions. In the first place, she thinks that the concept of a social formation is inextricably associated with orthodox Marxism, that is to say with a particular understanding of Marx's views on history that is both reductionist and determinist, and which is based solely on a casual reading of just one text, namely the Preface to Marx's A Contribution to a Critique of Political Economy. She also believes that Marx's version of historical materialism, properly understood, is neither reductionist nor determinist. Consequently, she considers it to be necessary to reject the concept of a social formation and to dissociate Marx from the use of it. I have suggested that this argumentative strategy is problematic, simply because, as Meiksins Wood acknowledges, the concept of a social formation is deployed by Marx himself, especially when talking about the transition from feudalism to capitalism. I have also argued that despite his use of this concept Marx is neither a determinist nor a reductionist. It must, therefore, be possible in principle to detach the concept of a social formation from any association which it might be thought to have with orthodox Marxism.

In the second place, as we have seen, there are occasions when Meiksins Wood associates the concept of a social formation specifically with the structuralist Marxism of Louis Althusser and his fellow contributors to Reading Capital, including Etienne Balibar. She erroneously maintains that the concept of a social formation, with its reference to an articulation of different modes of production, is an Althusserian addition to Marxism. In her opinion, this is another reason for objecting to the concept and for dissociating Marx from its employment. Two things might be said in response to this argument. First, the concept of a social formation is not necessarily associated with 
structuralist Marxism. On the contrary, as we have seen, it can be found in Marx's own writings. Indeed, as we saw earlier, E. P. Thompson was happy to deploy this concept, despite being a strong critic of Althusser and structuralist Marxism. Second, Meiksins Wood overlooks the very significant differences which exist between orthodox Marxism and structuralist Marxism, not least with respect to the underlying philosophical (i.e. ontological and epistemological) assumptions of these two theoretical frameworks.

Meiksins Wood rejects the concept of a social formation as something which is alien to the outlook of historical materialism as she understands it. At the same time, however, she wishes to retain the notion of a mode of production. In her view, therefore, these two concepts can and should be detached from one another. Moreover, she maintains that the concept of a mode of production is to be found in Marx's writings, whereas that of a social formation cannot. It is, rather, an alien intrusion or an unnecessary accretion which has (undesirably) been added to Marxism by later Marxists, specifically Louis Althusser and his structural Marxist disciples. Against this, it might be suggested that for Marx the concept of a mode of production and that of a social formation are necessarily connected to one another and stand or fall together. The entities to which these concepts refer are related to one another, as a part to the whole of which it is the part. Once the role that both concepts have to play in Marx's writings has been properly understood, it becomes clear that it is not possible to reject one of them without also rejecting the other. However, I do not see how anybody who wishes to be associated with Marxism could possibly reject the notion of a mode of production.

It is useful at this point to draw a distinction between orthodox Marxism and what I propose to call classical Marxism. The essence of my argument has been to suggest that the concept of a social formation is not in fact to be associated with orthodox Marxism, which is indeed both determinist and reductionist. It should, rather, be associated with classical Marxism, that is to say, the Marxism of Marx himself properly understood.

\section{Conclusion}

We have seen that Ellen Meiksins Wood presents herself as being in some sense a follower of E. P. Thompson. She is also a strong critic of the view that the concept of a social formation has an important part to play in the thinking of Marx and in classical Marxism after Marx. One problem with this view is that by holding it Meiksins Wood disagrees, not only with Marx himself, but also with E. P. Thompson. For Thompson's attitude towards the concept of a social formation is nothing like as critical and is far more positive than that of Meiksins Wood. When discussing the concept of a social formation, both Thompson and Meiksins Wood attach importance to what I have called the focal passage from the General Introduction to Marx's Grundrisse. However, they read this passage in very different ways. According to Thompson's reading, the focal passage supports the view that the concept of a social formation is of fundamental importance for Marxist historians, not least because of its association with the notion of reciprocal interaction. Ellen Meiksins Wood reads the focal passage very differently. In her opinion, it supports the opposite conclusion from the one that is drawn by Thompson. 
When discussing the focal passage from Marx's Grundrisse in her essay 'Rethinking Base and Superstructure,' Meiksins Wood arguably overlooks the real significance of what E. P. Thompson has to say about it (Meiksins Wood, 1995C). This is so because Thompson's reading of the passage presents a challenge to her own views regarding the significance of the concept of a social formation for Marx and for later Marxism. Thompson appreciate that the principle of reciprocal interaction between the component parts of a social formation, understood as a social totality or whole, has an important part to play in both Marx's social theory and his views regarding historical explanation. He rightly suggests that this implies the rejection by Marx of the principles of determinism and reductionism. However, it is less clear that Marx has the notion of reciprocal interaction specifically in mind in the focal passage, as opposed to the notion of modal combination. It may be suggested that the notion of modal combination, and therefore also by implication that of a social formation, which is to be understood by reference to it, has an important part to play in Marx's critique of determinism and reductionism. The significance of the notion of modal combination in the focal passage is either overlooked completely or its significance is downplayed by both E. P. Thompson and Ellen Meiksins Wood.

\section{NOTES}

'Marx, 1973, 106-07. Translation modified.

\section{BIBLIOGRAPHY}

Althusser, Louis. 1969a (1965). "Contradiction and Overdetermination." Pp. 87-128 in For Marx. Trans. Ben Brewster. Harmondsworth: Penguin.

Althusser, Louis. 1969b (1965). "On the Materialist Dialectic." Pp. 161-218 in For Marx. Trans. Ben Brewster. Harmondsworth: Penguin.

Althusser, Louis, Étienne Balibar, Roger Establet, Pierre Macherey and Jacques Rancière. 2015 (1965). Reading Capital: The Complete Edition. Trans. Ben Brewster \& David Fernbach. London: Verso.

Althusser, 2015a (1965). "From Capital to Marx’s Philosophy." Pp. 9-72 in Althusser, Balibar, Establet, Macherey and Rancière. Reading Capital: The Complete Edition.

Althusser, 2015b (1965). “The Object of Capital." Pp. 215-356 in Althusser, Balibar, Establet, Macherey and Rancière. Reading Capital: The Complete Edition.

Anderson, Perry. 1980. Arguments Within English Marxism. London: Verso.

Anderson, Perry. 1988 (1974). Passages from Antiquity to Feudalism. London: Verso. 
Arendt, Hannah. Between Past and Future: Eight Essays. London: Penguin.

Arendt, Hannah. 2006 (1954). "Truth and Politics." Pp. 223-59 in Between Past and Future: Eight Essays.

Aristotle. 1984. Metaphysics, trans. W. D. Ross. Pp. 1552-1728 in Jonathan Barnes ed., The Complete Works of Aristotle, Volume 2. Princeton, NJ.: Princeton University Press.

Arthur, Christopher J. 2008. "Guide to Marx’s Grundrisse in English.” Available at https//chrisarthur.net

Balibar, Etienne. 2015 (1965). "On the Basic Concepts of Historical Materialism.” Pp. 35948o in Althusser, Balibar, Establet, Macherey and Rancière. Reading Capital: The Complete Edition.

Bauer, R. A. 2013 (1952). “The Behavioural Psychologies of the Twenties.” Pp. 49-66 in The New Man in Soviet Psychology (Cambridge, MA.: Harvard University Press.

Cornforth, Maurice. 1974 (1954). "Mind and Body." Pp. 9-21 in Dialectical Materialism, Vol. III, Theory of Knowledge. London: Lawrence \& Wishart.

Establet, Roger. 2015 (1965). "Presentation of the Plan of Capital." Pp. 481-530 in Althusser, Balibar, Establet, Macherey and Rancière. Reading Capital: The Complete Edition.

Graham, Loren R. 1987. "Physiology and Psychology.” Pp. 157-219 in Science, Philosophy and Human Behaviour in the Soviet Union. New York: Columbia University Press.

Hirst, P. Q. 1985a. “The Necessity of Theory: A Critique of E. P. Thompson's The Poverty of Theory." Pp. 57-90 in Marxism and Historical Writing. London: Routledge.

Kaye, Harvey J. 1984. The British Marxist Historians. Cambridge: Polity Press.

Kaye, Harvey J. 1984a. "E. P. Thompson on the Making of the English Working Class." Pp. 167-220 in The British Marxist Historians. Cambridge: Polity Press.

Malinin, V. A. et. al. eds., 1974. Fundamentals of Marxist-Leninist Philosophy. Moscow: Progress Publishers.

Marx, Karl. 1958 (1852), The Eighteenth Brumaire of Louis Bonaparte. Pp.247-344 in Karl Marx and Frederic Engels, Selected Works, in 2 Volumes. Moscow: Foreign Languages Publishing House.

Marx, Karl. 1973 (1857-1858). Grundrisse: Introduction to the Critique of Political Economy, trans Martin Nicolaus. Harmondsworth: Penguin. 
Marx, Karl. 1981 (1859). A Contribution to the Critique of Political Economy. Ed \& intro Maurice Dobb, trans. S. W. Ryazanskaya. London: Lawrence \& Wishart.

Marx, Karl and Frederick Engels. 2007 (1845). The German Ideology, $2^{\text {nd }}$ ed. Ed. \& intro Christopher J. Arthur. London: Lawrence \& Wishart.

Marx, Karl and Frederick Engels. 1958. Selected Works, in 2 Volumes. Moscow: Foreign Languages Publishing House.

Marx, Karl and Frederick Engels. 2010. Collected Works in 50 volumes. London: Lawrence \& Wishart.

Marx, Karl. 2010a (1859). "Preface." Pp. 261-66 in Karl Marx, A Contribution to the Critique of Political Economy. Collected Works, Vol. 29, Marx E Engels: 1874-1883. London: Lawrence and Wishart.

McLeish, John. 1959. “Contemporary Soviet Psychology” New Reasoner, 8, 83-88.

Meiksins Wood, Ellen. 2000 (1995). Democracy Against Capitalism: Renewing Historical Materialism. Cambridge: Cambridge University Press.

Meiksins Wood, Ellen. 200oa (1995). "Introduction." Pp. 1-19 in Democracy Against Capitalism: Renewing Historical Materialism. Cambridge: Cambridge University Press.

Meiksins Wood, Ellen. 2ooob (1995). "Rethinking Base and Superstructure.” Pp. 49-75 in Democracy Against Capitalism: Renewing Historical Materialism. Cambridge: Cambridge University Press.

Meiksins Wood, Ellen. 200oc (1995). "History or Technological Determinism?” Pp. 10845 in Democracy Against Capitalism: Renewing Historical Materialism. Cambridge: Cambridge University Press.

Meiksins Wood, Ellen. 2oood (1995). "History or Teleology: Marx Versus Weber." Pp. 14678 in Democracy Against Capitalism: Renewing Historical Materialism. Cambridge: Cambridge University Press.

Nield, Keith \& John Seed. 1979. "Theoretical Poverty or the Poverty of Theory: British Marxist Historiography and the Althusserians." Economy and Society, 8, 4, 383-416.

Poulantzas, Nicos. 1976 (1968), Political Power and Social Classes (London: New Left Books.

Skinner, B. F. 1972. Beyond Freedom and Dignity. Harmondsworth: Penguin.

Thompson, E. P. 1957a. “Socialist Humanism, I.” The New Reasoner, 1, 105-15.

Thompson, E. P. 1957b. “Socialist Humanism, II.” The New Reasoner, 1, 124-43. 
Thompson E. P. 1965. “The Peculiarities of the English.” The Socialist Register, 2, 311-62.

Thompson, E. P. 1978. "Folklore, History and Social Anthropology." Indian Historical Review, 3, 2, 247-66.

Thompson, E. P. 1981a. “The Poverty of Theory: Or, an Orrery of Errors.” Pp. 193-398 in The Poverty of Theory and Other Essays. London: Merlin Press.

Thompson, E. P. 198ob. “Open Letter to Lezsek Kolakowski.” Pp. 92-192 in The Poverty of Theory and Other Essays. London: Merlin Press.

Thompson, E. P. 1994. Making History: Writings on History and Culture. New York: The New Press.

Thompson, E. P. 1994a. "History and Anthropology." Pp. 200-25 in Making History: Writings on History and Culture. New York: The New Press.

Thompson, E. P. 1994b. "Agenda for a Radical History." Pp. 358-64 in Making History: Writings on History and Culture. New York: The New Press.

Williams, Raymond. 1977. Marxism and Literature. Oxford: Oxford University Press. 